\title{
When It Takes a Network: Creating Strategy and Agility THROUGH WARGAMING
}

\author{
Arnoud Franken \\ Harry Thomsett
}

Rational, analytical, directed approaches for strategy creation and execution may work for creating value by conventional, hierarchically structured organizations operating in stable environments. However, when the basis of competition shifts from product features to an experience delivered by a network of independently acting participants in a complex and fast-evolving market environment, approaches based on command and control do not work. For order to emerge from such chaos and to gain more control over success, strategy based on reason alone is not enough to inspire action in others. To understand what it takes to effectively make strategy under such circumstances, this article shows how the UK's Royal Marines, in collaboration with more than a dozen different stakeholder groups, developed a novel adaptation of wargaming to affect strategic change in Afghanistan. It also demonstrates the broad applicability of this strategic approach. (Keywords: Strategy Making, Strategic Agility, Wargaming, Networks)

n response to constantly evolving market pressures, pioneering companies have always sought new ways of structuring information flows and arranging assets and resources to create offerings customers want and expect. Therefore, as the basis of competition shifted over time from capital to information and now innovation, organizational designs coevolved with it. In the late nineteenth and early twentieth century, organizations were designed to best utilize physical assets for the efficient mass production of standardized products through centrally coordinated, vertically integrated hierarchies. To keep pace with the movement from standardized to customized products and services in an increasingly deregulated global market place, the mid- to late twentieth century saw organization designs shift to matrix and value chain forms that were better geared to utilizing information. Today, in the face of unprecedented pressures to rapidly and continuously adapt to a complex, dynamic, uncertain, and highly interconnected global environment, many organizations are moving towards multi-firm or multi-actor network designs. ${ }^{1}$

In moving to a network design, leading organizations are going beyond transactional relationships with upstream and downstream partners typical of 
Arnoud Franken is a Senior Research Fellow at Cranfield School of Management, researching and consulting on strategy and business change. <arnoud.franken@cranfield.ac.uk>

Harry Thomsett is a former Royal Marines officer and Deputy Head of Security for the Olympic Park and Athletes' Village at the London 2012 Olympic and Paralympic Games. traditional supply chain models. They are developing trust-based, mutually beneficial, and enduring relationships with diverse participants to co-create customer solutions or experiences. As part of this process, organizations tend to shrink their organizational activities and rely increasingly on others to complement these for profitable growth. However, how far organizations go with this differs (see Figure 1). ${ }^{2}$

The topic of organizational design has recently seen an increase in scholarly interest, triggered by design challenges such as agility, resilience, customer centricity, social responsibility, and innovation. However, the question of how to make strategy (i.e., the intellectual act of creating strategy and the practical act of executing strategy) in a multi-actor network context appears to have received little attention in the literature to date. The purpose of this article is to address this gap and develop a practical approach for strategy making by networks along the "closed community/managed ecosystem" axis. The reason for focusing on these network designs is that they appear more relevant for businesses desiring to move beyond traditional supply chain models than for the radically different open-community model. (From here onwards, these two network types will simply be referred to as "networks".)

\section{Strategy as a "Wicked" Problem}

The shift to competing through networks creates new challenges for strategy making across organizational boundaries. The reason is that these networks are broader in scope than the conventional idea of a supply chain where the focus is on the roles participants play in the order fulfillment process ("extended enterprise," see Figure 1). Here, the decision by an organization to participate may be dependent on the willingness or reluctance of other similar or different organizations to participate (e.g., leading hardware, software, telecommunication companies, and major content providers in the cases of Apple and Google), or it may be a necessity to attract certain customers but an obstacle to reach others. Hence, the relationships between participants within and across these networks are not linear and static but interdependent and dynamic. This leads to the emergence of complex, unpredictable, and largely uncontrollable participant and network behaviors. $^{3}$

These situations pose what Horst Rittel and Melvin Webber called "wicked" problems-problems that are difficult to come to grips with and that constantly change in unexpected and irreversible ways whenever participants act. ${ }^{4}$ Tackling these problems cannot be done by network participants independently as that would only exacerbate the problem, rather it requires collaboration-even if by a small cluster of participants just to get started. ${ }^{5}$

To deal with these challenges, the strategy and complexity literature suggest the adoption of a combined deliberate and emergent strategic planning approach. ${ }^{6}$ Although relevant in principle, many of these approaches tend to focus only on 
FIGURE I. Taxonomy of Network Designs (after Gulati, Puranam, and Tushman *)



* Adapted from Table I in R. Gulati, P. Puranam, and M. Tushman, "Meta-Organization Design: Rethinking Design in Interorganizational and Community Contexts," Strategic Management Journal, $33 / 6$ (June 20 I2): 57 I-586. Copyright (C) 2012 John Wiley \& Sons, Ltd. This material is reproduced with permission of John Wiley \& Sons, Inc.

strategy formulation, ignoring the practical act of strategy execution that is key to transforming ideas into reality—an area where many organizations struggle. ${ }^{7}$ Further, they tend to view planning from the perspective of a single focal organization, which offers the benefits of enabling the use of the organization's corporate identity to provide direction and focus attention on threats and opportunities. ${ }^{8}$ However, an emerging network lacks such an identity and it cannot be assumed to view 
the world from the outset through a single lens as participants will come to it with different, perhaps even competing, perceptions. This also highlights the role of emotion and meaning in inspiring participants to join, something that these planning approaches tend to overlook in favor of reasoning. ${ }^{9}$ Related to this, whereas executives of a focal organization have the statutory mandate to direct strategy, these leaders lack the power to do this at the network level as each participant is free to act. ${ }^{10}$ Competing successfully as a network, therefore, presents a broader range of practical issues than have been addressed by the extant literature. In particular, it requires an approach that can reconcile competing viewpoints into a shared situational understanding, create a compelling purpose, and maintain unity of effort across a diverse and leaderless network to achieve commonly desired outcomes in the face of wicked problems.

\section{Challenges to Strategy Making in the Face of "Wicked" Problems}

\section{Wicked Problems}

The roots of the traditional strategy schools of design, positioning, and planning-which dominate the strategy literature, MBA strategy courses, and practice-can be traced back to the industrial age. ${ }^{11}$ In that era, the idea that pervaded management thinking, and continues to do so in government and industry today, was efficiency. By viewing the machines that were the source of wealth in that period as a model for business, strategy became regarded as a process of designing solutions for structurally complex problems, based on the premises that:

- it is possible to know all that needs to be known to create perfect plans, as the world can be seen as consisting of separate "objects" that behave in linear fashion;

- managers create these plans and workers execute these as instructed, i.e., planning and execution are separate activities; and

- there is only one way to achieve optimal performance and workers' initiative is thus not desired. ${ }^{12}$

Specifically, under these conditions the strategy process becomes one of diligent rational analysis where executives set and review objectives, identify strategic options, allocate resources, and coordinate, monitor, and control the programming and implementation of initiatives by lower level managers.

However, the social world is not a structurally complex system like a machine where the freedom of action by the constituent parts is limited. Instead, it is an interactively complex system where participants are free to act according to their own circumstances and requirements. By doing so, players create effects that simultaneously change the circumstances and requirements of other participants. As a result of the free interactions between the interconnected participants, these systems behave in complex, unpredictable, and largely uncontrollable ways. This emergent complex behavior, however, is changeable: participants create, deactivate, and change the strength of their social ties over time for any number of reasons, which changes their behavior as well as the structure of the networks in which they participate. ${ }^{13}$ 
Contrary to the (flawed) assumptions underpinning the traditional strategy schools, business environments are, therefore, not characterized by repeatable cause-and-effects that can be understood better by collecting more information or building more sophisticated models. Instead, they are characterized by the continuous cascading of irreversible effects, resulting from innumerable causes and interactions that are not mathematically computable. Hence, information about the social world:

- is infinite, volatile, complex, uncertain, and ambiguous;

- has a time-dependent value;

- is not necessarily true, accurate, or known, and which may be known, unknown, or unknowable;

- can reasonably be interpreted in more than one way as it is dependent on individual perceptions, shaped by cultural values and norms, knowledge, experience, and cognitive biases such as confirmation bias, anchoring, loss aversion, and overconfidence; and

- may be hard to capture in discrete form (for example, it is difficult to clearly articulate emotions, for which people rely on metaphors, imagery, and analogies-even if information can be captured in discrete form, different pieces of information may not necessarily fit seamlessly together like jigsaw puzzle pieces). ${ }^{14}$

The learning school recognizes these challenges, leading to an emergent approach to strategy planning based on the premises that:

- complex environments preclude deliberate control;

- strategies evolve as a result of an organic, reactive, learn-as-you-go approach, first as patterns out of the past and only later as plans for the future; and

- the role of leadership is to manage the strategic learning process, not to preconceive deliberate plans.

Although these premises are valid, they are only so to a degree. First, environments may be complex, but that does not preclude players from taking initiative. Control is therefore not impossible but limited. Further, without some degree of understanding of what needs to be achieved and how, a pure emergent approach becomes too reactive to external threats and opportunities, which is high risk in today's failure intolerant business world. A combined deliberate and emergent approach is thus needed for progressing with purpose in the face of volatile, complex, uncertain, and ambiguous environmental conditions. ${ }^{15}$

As mentioned earlier, Rittel and Webber referred to such conditions as "wicked" problems (the problems scientists and engineers focus on are referred to as "tame" or "benign") and identified the following characteristics:

- the problem is not understood until after the formulation of a solution;

- wicked problems have no stopping rule;

- solutions to wicked problems are not right or wrong;

- every wicked problem is essentially novel and unique;

- every solution to a wicked problem is a "one shot operation"; and

- wicked problems have no given alternative solutions. ${ }^{16}$ 
Dealing with these problems has significant implications for strategy making, i.e., strategy creation and execution. It requires an approach that is more sophisticated than a simple combination of the deliberate and emergent schools, as the nature of the problems to tackle is social, not scientific.

\section{Implications for Strategy Creation}

According to strategic theory, strategy is concerned with the coherent linking of ends (goals), ways (the how), and means (resources, including individuals' or organizations' willingness to act) based on assumptions about the environment and the problem at hand. To be effective, a strategy must include prioritization of goals, sequencing of actions (since sufficient resources are not always available to pursue all goals simultaneously), and measures to determine success. Given the nature of interactively complex problems, this is an iterative process, as information about unfolding events will not only verify or discredit underpinning assumptions (or highlight deficiencies in the original plan), but also indicate the emergence of new threats and opportunities that will need to be addressed. ${ }^{17}$

The strategy creation process is composed of a number of steps, which are preceded by a leader (an individual or organization) recognizing the need for action:

- identifying, engaging, and involving relevant stakeholders and subject matter experts (individuals and/or organizations);

- environmental scanning to develop situational understanding;

- developing a shared purpose or vision;

- identifying tasks and understanding operating constraints (which combined with answers from the previous steps inform the development of possible courses of action); and

- detailed planning of a chosen course of action for implementation.

\section{Stakeholder Participation}

As an individual leader is likely to lack the ability to get a grip on wicked problems, a collection of stakeholders or subject matter experts, each having different perspectives and insights relevant to the problem at hand, may be able to tame the problem sufficiently to move forward with confidence. This means that the strategy planning process needs to be inclusive-vertically and laterally. However, for this process to be productive it must take place within a context of an inspiring cause, i.e., it must hold intrinsic interest for others to want to join the emerging network. To affect this, the leader needs to understand what matters to her as well as what others care about to identify a common cause that will bring diverse participants together. Further, during the engagement, participants must have the feeling that their contribution is heard and valued, which requires relationships based on trust, open minds, and a willingness to listen. When such conditions exist, people tend to experience an energizing effect or sense of personal fulfillment from contributing to something that is larger than themselves. In other words, they will be intrinsically motivated to make a difference. ${ }^{18}$ 


\section{Environmental Scanning}

An inclusive planning process needs to be based on open communication between participants as the development of common situational understanding results from interpreting environmental data and internalizing diverse perspectives through inquiry and advocacy. The latter is an iterative shaping or learning process that can take place through first-hand experience as well as vicarious experiences such as simulations, gaming, or observations, including case studies. ${ }^{19}$ To be effective, this learning process needs to be guided by asking the right questions. For example, questions that help to:

- identify and understand past blind spots, i.e., events that were missed in the past and had major consequences;

- find suitable analogies from other industries to see a similar situation through different lenses, which may reveal unexplored risks and opportunities;

- identify important signals that are normally rationalized away and/or subject matter experts who can provide unconventional perspectives; and

- identify possible future surprises (good and bad), emerging developments that could change the rules of the game, as well as "unthinkable" scenarios that would be easily dismissed as highly unlikely but may contain key indicators that provide early warning for impending change. ${ }^{20}$

\section{Shared Purpose or Vision}

Regardless of the type of learning experience, the process of inquiry and advocacy is mediated through dialogue or storytelling. It is through the narrative process that participants explore and make sense of strategic issues at a personal level, reach consensus, and develop a deeper sense of shared purpose than can be achieved through rational analysis. Hence, it creates a shared frame of reference that acts as a touchstone for decision making, something that is assumed present in intra-organizationally focused approaches. ${ }^{21}$

\section{Courses of Action}

The dialogic process that gives rise to a shared purpose also creates in participants' minds a cognitive gap between their current view of reality and the desired state. This gap forms the basis for the discovery of alternative solutions through the connection of diverse insights and competencies. To facilitate choosing between alternative solutions or options, dialectic processes such as red teaming (e.g., devil's advocacy, role-playing, surrogate adversary, Team A/Team B, and decision markets) are needed. These contrarian approaches challenge assumptions and beliefs rather than seek consensus and commitment, thereby improving the quality of decisions. In other words, the planning process must combine divergent and convergent thinking. ${ }^{22}$

\section{Planning for Action}

Lastly, to be effective and support rapid implementation, an inclusive planning process must also have a rational element that facilitates the coherent linking 
of ends, available ways, and existing means such that it enables participants to overcome identified challenges in pursuit of desired outcomes. This includes understanding what means are available across the network and when, who will be responsible for what, dependencies between participants and activities, priorities and timings, and operating boundaries. Given the uncertainty and ambiguity of the environment, the strategy created at this stage cannot be a single focused line of attack as emphasized by traditional approaches. Instead, the strategy must be robust, i.e., it must be capable of performing well in a variety of possible future scenarios based on risk factors identified in earlier steps. To effect this and reduce the network's exposure to environmental uncertainties, a strategy can contain preliminary actions to "shake the tree" (i.e., piloting small, diverse actions and observing responses to explore the environment and reduce uncertainty), branch plans that deal with or take advantage of uncertain events if and when these take place, as well as contingency plans in the case of show-stopping events. ${ }^{23}$

In summary, for a network-based strategy creation process to be effective, it must take the form of an interactive and collaborative storytelling process, the emerging narrative being the strategy in which participants understand not only their roles, but also their freedom to improvise. Contrary to the traditional strategy schools, this perspective recognizes the multiple and interlinked realities different network participants bring to the table, and serves as a lens through which apparently independent and disconnected events and perceptions are seen as related parts of a whole. As such, the process facilitates the development of meaning and purpose, provides direction, expands perception (and thus choices and action repertoires), and is intimately tied to participant acceptance, approval, and adoption through their early engagement.

\section{Implications for Strategy Execution}

As General Dwight D. Eisenhower once said, "In preparation for battle I have always found that plans are useless, but planning is indispensable." Underpinning this insight is the recognition that unforeseen and unforeseeable factors such as mistakes, delays, emerging opportunities, and chance events can create enormous difficulties for the realization of any plan. In complex and fast-evolving environments, such unexpected events are to be expected. It is for this reason that purpose is always more important than any pre-defined task. However, it also indicates the importance of being able to adapt rapidly (response) and flexibly (range of options) to new and potentially disruptive developments during the execution of strategy in order to achieve desired outcomes.

At the operational level, this adaptive ability is referred to as "strategic flexibility." It focuses on an organization's ability to respond to a variety of requirements, which exist within defined constraints, either rapidly (e.g., quickly increasing or decreasing production volumes) or flexibly (e.g., switching from producing one option to another) or both. At the strategic level (organization and network), this ability is referred to as "strategic agility," and it focuses on the ability to adapt rapidly and flexibly to unforeseen changes in the external environment. These two concepts both refer to coordination and resource flexibility. Yet, they apply at different levels 
and are complementary- "agility" at the organizational and network levels requires "flexibility" at the operational level. ${ }^{24}$

According to the literature on strategic agility, the ability to adapt rapidly and flexibly is based on the presence of three meta-capabilities:

- sensitivity - the ability to quickly identify and make sense of incipient trends and developments as they emerge and evolve;

- unity - the ability to rapidly respond as one in the face of changing circumstances to achieve common goals; and

- fluidity-the ability to easily re-organize people, resources, processes, and systems to suit the task. ${ }^{25}$

When these meta-capabilities are in place, an organization or network is able to recognize when events render original plans obsolete ("sensitivity"), to decide how best to adapt ("unity"), and is motivated to move forward ("fluidity"). The foundation for these meta-capabilities is laid during the planning stages, which re-establishes the connection between strategy planning and execution.

Of course, agility doesn't happen by itself-it is the result of people making and acting upon decisions. In traditional, hierarchically structured organizationswith clear divisions of roles and accountabilities, and knowledge and power concentrated at the top-these decisions are essentially directed and controlled by the executive leadership. However, in networks this is typically not the case: knowledge and power are dispersed. Each participant that joins the network is equal to any other participant, and each is responsible for his or her own actions. Enacting agility at the network level thus requires a different approach to leadership and management. From the literature on complex adaptive systems, it follows that this is achieved through ideology, i.e., a shared purpose, values, norms, and beliefs that act as a touchstone, complemented by inspirational, collaborative, and boundaryspanning leadership at all levels. This underscores the importance of an inclusive planning approach. Further, when people and organizations come together with the same belief systems and purpose, trust emerges. This encourages self-organization around information, the creation of relationships to effect decisions with others, and mutual support. It is this fundamental desire to share and contribute, fuelled by a sense of shared purpose, that gives rise to unity of effort during execution of strategy and achieves progress in the face of challenging environmental conditions. ${ }^{26}$

\section{Strategy Making as a Form of Play}

Upon reflection, the activities identified in the previous sections as necessary elements for an approach to strategy making by networks show a remarkable resemblance to the elements of social play. For example, children and young animals learn about their world and the rules of engagements with friends and foes through exploration, role-playing pretend narratives, and imagining possibilities (i.e., simulation and testing, in a penalty-free setting). By engaging in play activities, they

- improve their problem-solving and creative thinking abilities,

- increase their self-motivation and confidence, 
- improve their emotional intelligence and ability to interact socially,

- develop a shared language and identity that can be used in future strategizing, and

- enhance their sense of involvement and ownership, which contributes to team building and group cohesion. ${ }^{27}$

Play is thus about more than simply practicing physical, intellectual, and social skills needed in the future. Play is also a means to quickly learn how to navigate the world and adapt to it without being directly at risk. Far from being a non-productive activity only for children, its evolutionary purpose is to prepare us for the unexpected in novel environmental and social circumstances. As the social world constantly changes in complex, unpredictable, and largely uncontrollable ways, play remains of vital importance throughout life. Those who stop developing and exploring new territories (e.g., through engaging in sports, books, storytelling, arts, acting, movies, research, and professional development) share the same fate of all animals that grow out of play. Their behavior becomes fixed and performance declines. This also applies to organizations. ${ }^{28}$

The purpose of the strategy-making process-in particular, the aspect of strategy creation-is the same as that of play: to prepare the organization for the unexpected in order to survive and thrive. Given that strategy making is a social process and humans are hardwired to play together, it is perhaps no coincidence that the same elements feature in both activities.

Strategy making, however, is not like the free-play children engage in:

- the process tends to be more structured;

- the roles of participants are usually fixed;

- there are a priori rules that must be followed (e.g., physical, legal, and ethical), while others can be creatively challenged during the process (e.g., basis of competition); and

- penalties for mistakes made during the execution phase can be serious (e.g., loss of customers and revenue, decline in share price, reputational damage).

This brings strategy making closer to the notion of gaming.

The difference between play and gaming, however, is fuzzy, as both concepts are difficult to define. At a basic level, play and gaming are, like love, primal, preconscious, and preverbal activities. They are characterized by freedom and flexibility. Anyone can engage in them, but what is play or a game to one (e.g., parachuting from a airplane) is not necessarily the same for another. In general, however, play and gaming can be described simply as "non-serious" variants of functional behavior. In play, the emphasis tends to be on the enacted behaviors rather than the function, and participants can choose to reciprocate roles. In games, rules tend to be pre-determined and participants are expected to follow these or face some form of penalty (e.g., three strikes and you're out in a baseball game). However, not all games are alike. Some games have few rules that are applied flexibly (e.g., improvisational theatre), making them similar to play, whereas others have many rules that are more rigidly enforced (e.g., many sports, board and video games). ${ }^{29}$ 
Bringing together the notions of strategy and gaming is not new, as demonstrated by the frequent use of sports metaphors in business. More specifically, simulating strategy or tactics based on real, historic, anticipated, or potential environments without risking resources and effort is as old as strategy itself. Derived from military practices, these simulation processes are often referred to as "wargaming." In its common form, wargaming is a structured interactive approach in which a group of stakeholders or players test one or more proposed strategies or tactics. This dialectic process can be carried out on a tabletop or whiteboard, which allows freedom to develop understanding. It can also be performed on a computer, in which case the analysis is more data and algorithm-driven. Scenario thinking or planning is a variant of wargaming. Here the emphasis tends to be on imagining and testing plausible futures and making flexible long-term plans, i.e., it is a more play-like, dialogic process. ${ }^{30}$

\section{From Theory to Practice}

The literature offers numerous practical and/or conceptual suggestions for dealing with the issues discussed earlier. A practical framework that integrates all the dialogic, dialectic, emotional, and rational elements identified as necessary for network-based strategy making in the face of wicked problems appears to be lacking. The concept of gaming, however, may offer insight into how to accomplish this.

As part of a three-year research project by one of the authors into the extreme adaptability of the UK's elite Royal Marines, it came to light that their 3 Commando Brigade had successfully developed and applied a wargaming-based approach for strategy making by networks. This approach had come about as a result of unexpected changes in circumstances during their 2008/2009 Afghanistan deployment. It was developed by thirteen people within the Brigade Headquarters' Core Planning Team: four women from the media, government, legal, and police; the Head of the Provincial Reconstruction Team and his deputy; a representative of the Danish unit attached to the Brigade; and six senior Royal Marines staff officers. The other author of this article was one of these officers.

For the research reported here, we were able to gain access to and interview in-depth the six Royal Marines officers involved only (three Majors, two Lieutenant Colonels, and a Brigadier General). These interviews, informed by the literature, lasted between 1 and 2 hours. In a number of instances, multiple meetings were held with the same individuals to explore emerging insights in more detail or from different perspectives to ensure greater reliability. In total ten interviews were conducted. These interviews were transcribed, analyzed, and written up into a case study by one of the authors. This case study was reviewed independently by two of the officers interviewed for accuracy. Further, given his security clearance at the time, the other author was able to verify, and correct where necessary, particular aspects by means of the formal (classified) campaign records. This case study was then used to explore how the Royal Marines had integrated the elements identified separately from the literature into a practical framework. 


\section{The Royal Marines' Experience}

\section{Dislocation of Expectation}

On October 8, 2008, the Royal Marines of 3 Commando Brigade started their third tour of duty in Afghanistan's Helmand province. In the preceding twelve months, the Brigade had prepared meticulously for their role in implementing the next phase of NATO's International Security Assistance Force (ISAF) mission. However, three days into their tour, information was rapidly coming in through communication intercepts, informants, and patrol reports that contradicted the expectations that underpinned the Royal Marines' campaign strategy. They had assumed that the Taliban would lack the intent and capability to execute a major assault in Central Helmand, home to the Provincial Governor and 3 Commando Brigade HQ, after a hard summer of fighting with the Marines' predecessors, 16 Air Assault Brigade. Consequently, the area was very lightly defended. This turned out to be a mistake. Unprecedented, three to four hundred Taliban fighters were reported approaching the provincial capital from multiple directions with the intent of killing the governor and ejecting ISAF from Central Helmand. If successful, it would enable the Taliban to claim a strategic victory. This prospect shocked everyone in Brigade HQ as it would mean mission failure, do considerable damage to the Royal Marines' long and proud reputation, and have far-reaching consequences for the success of NATO's mission in Afghanistan. This was unacceptable. Fortunately, the outnumbered Royal Marine, NATO, and Afghan national security forces in the provincial capital were able to cause the Taliban to retreat after an intense battle-for the moment.

\section{Chaotic Situational Understanding}

The temporary defeat of the Taliban, a militant and political network driven by an extreme Islamic ideology, in the battle for the hearts and minds of the Afghan population was no cause for celebration. The Royal Marines knew that they had been fortunate that their information was good even if their strategy was less so. However, unless this unexpected threat was addressed quickly, it could re-emerge and cause havoc. As 3 Commando Brigade's existing campaign strategy was unable to prevent this from happening, it was discarded. A new strategy was needed but time and resources were limited. Crucially, it would require the support and involvement of more than a dozen stakeholders, many over whom the Royal Marines had little to no control (see Figure 2). To complicate matters, not all stakeholders, some of them very powerful, agreed that a new strategy was even necessary. Those stakeholders that did appreciate the need for change had different reservations about its implications. This made the situation faced by 3 Commando Brigade HQ highly complex and ambiguous. The multiple uncertainties concerning the Taliban's next moves and the large number of stakeholders-each having different beliefs, interests, and capabilities_could interact in so many unpredictable ways that potential outcomes were impossible to predict. Not only that, this high level of ambiguity hindered the rapid development of a new, effective strategy, as this requires a good enough understanding of the environment. The risks of proceeding without this understanding would be unacceptably high.

The Brigade commander and his staff appreciated that their conventional approach for creating situational awareness, strategy, and plans could not deal 
FIGURE 2. The Network of Stakeholders Within Which 3 Commando Brigade HQ Operated During Their 2008/9 Deployment to Afghanistan's Helmand Province



effectively and efficiently with the situation faced. This approach was well suited for predictable force-on-force scenarios and hierarchical commands common in Cold War era scenarios, but not for today's fast-evolving interactions within and between networks of diverse stakeholders acting according to their own circumstances and requirements. To solve this problem, the Royal Marines needed an approach that could gradually reduce the level of ambiguity faced and help move the widely distributed collection of stakeholders to a position in which they would behave like a single purposeful entity—of their own volition. It struck one Royal Marine officer in the Brigade HQ that one strategy tool that naturally accommodates multiple participants and perspectives is wargaming. However, the Marines' approach to wargaming was geared to testing proposed courses of action before risking resources and effort. To make it appropriate for strategy making, the Core Planning Team applied the principles of wargaming in novel ways, defining the approach more broadly as “a structured interactive work-through of an actual 
or assumed real-life situation or problem [a narrative] using the principles of gaming," thereby opening the approach to include dialogic processes.

\section{Scenario Wargaming}

Getting the right internal and external stakeholders to participate was the first step of the transformed wargaming process (see also Sidebar 1). There were three reasons for this. First, in order to form a new strategy, the Royal Marines needed to understand the situation at hand better. The information they had relied on to inform their previous strategy had been proven to be inadequate. More and in particular different sources of insight were needed. Although some of these insights could be gained through the Royal Marines' own intelligence channels, others were only available through their external stakeholders. Second, the intelligence gathered from the various sources had to be synthesized, requiring the combined knowledge and experience of stakeholders, and then turned into a shared situational understanding upon which all could and were willing to subsequently act. Third, although some stakeholders would not be able to shape the new strategy or be part of its execution, e.g., the media, they would judge the consequences. As their opinions could affect the strategic outcome, e.g., through news reporting, their early engagement was critical.

\section{SIDEBAR I. Practical Considerations for Wargaming}

\section{How are stakeholders identified?}

Initially, judgment and conventional stakeholder management tools can be used to identify key stakeholders. As the process progresses, it should become obvious if or when a key perspective is missing. The membership of a wargaming group therefore needs to be flexible to ensure that the emerging narrative is subjected to the experience and perspective of new minds.

There is always the potential for the balance of stakeholders to be wrong or for some stakeholders to exert too much influence. This is why the role of the game controller is key (see Figure 2). This individual must provide the structure, discipline, and rigor necessary to enable constructive engagement between the stakeholders and the strategic problem being considered such that no stakeholder becomes too influential or dominant. Without strong facilitation, the wargaming approach may create more problems than it solves.

\section{How long should wargaming last to be effective?}

We need to distinguish between a wargame and the process of wargaming. A wargame may last between one and three hours, while 
the process of wargaming may constitute several wargames conducted over, for example, a two- to three-week period. The issue under consideration at the start of any given wargame is to be tightly framed even if the strategic problem being considered by the wargaming process is unbounded at the outset. When used for the purpose of strategic adaptation, the wargaming process is iterative with the membership changing as the strategic problem becomes more bounded and a common narrative and understanding emerges.

\section{What are some of the limitations of the wargaming approach?}

As mentioned earlier, without strong facilitation, the wargaming approach may create more problems than it solves. Further, there can also be cultural resistance to the approach, particularly in organizations that are traditionally "top-down" or where broad consultation is not the norm. This, too, can be overcome by strong facilitation. Finally, as with any approach, the quality of the results produced are dependent on the quality of the upfront effort-garbage in, garbage out.

Creating a shared understanding of the situation was the second step. This entailed identifying and understanding the range of potential explanations for what had happened; the potential futures for each explanation; and implications for any counteractions. To this end, all stakeholder representatives were asked in turn (see Figure 3) to provide an explanation from their perspective for the unexpected Taliban attack, using the most recent intelligence available. Further, the stakeholders placed themselves in the shoes of the Taliban commanders to try and see the situation from their point of view. By collating these diverse perspectives, a number of hypotheses started to emerge about potential causes and consequences. These ranged from "The Taliban attacked because they believed ISAF was weak" to "The Taliban attacked because they believed they were weak."

The plausibility of each hypothesis was tested by submitting it to the adversarial process of action-reaction-counteraction to see if it could explain how the Taliban had pulled off the attack. That is, at key moments along the elapsed timeline, each stakeholder was asked what their actions were at those times, followed by potential enemy reactions based on their assumed intent and capability in the given hypothesis. Next, given a plausible enemy reaction, each stakeholder considered what his or her counteractions should have been in order to prevent or obstruct that reaction. By repeating this process for a number of different hypotheses, patterns started to emerge. For example, despite the fact that the actions of two hypotheses would be different, leading to different Taliban reactions, the counteractions would frequently be the same or similar. For instance, a recurring counteraction was "gathering intelligence on Taliban activity around the provincial capital." One of the reasons this hadn't happened in the lead-up to the Taliban's surprise attack was that the Royal Marines' limited intelligence gathering 
FIGURE 3. A Tabletop Perspective of the Wargaming Layout for Developing Situational Awareness, Strategy Making, and Rehearsal

\begin{tabular}{|c|c|c|c|}
\hline & $\begin{array}{c}3 \text { Commando brigade } \\
\text { HQ planners }\end{array}$ & Wargame controller & \\
\hline $\begin{array}{l}\text { Battle group } \\
\text { (Centre South) }\end{array}$ & \multirow{5}{*}{\multicolumn{2}{|c|}{$\begin{array}{l}\text { Where participants sit is important as it } \\
\text { determines when people take turns in the } \\
\text { wargame. } \\
\text { ction. Brigade HQ planners start the round and } \\
\text { then each of the stakeholders to his/her right } \\
\text { states what they are doing on that turn. The } \\
\text { same then happens for those on his/her left. }\end{array}$}} & Intelligence (Blue) \\
\hline $\begin{array}{c}\text { Regional command } \\
\text { (South) }\end{array}$ & & & Logistics \\
\hline Battle group (South) & & & $\begin{array}{c}\text { Communications and } \\
\text { information }\end{array}$ \\
\hline Battle group (Centre) & & & Host nation support \\
\hline $\begin{array}{l}\text { Information } \\
\text { exploitation }\end{array}$ & & & Finance \\
\hline $\begin{array}{l}\text { Military stabilization } \\
\text { support teams } \\
\text { (MSSTs) } \\
\end{array}$ & \multicolumn{2}{|c|}{$\begin{array}{l}\text { Counter-action. It is then the red teams turn } \\
\text { to state what they would do in that situation. }\end{array}$} & $\begin{array}{c}\text { Provincial } \\
\text { reconstruction team } \\
(\mathrm{PRT})-\text { Governance }\end{array}$ \\
\hline $\begin{array}{c}\text { Joint helicopter force } \\
\text { (Afghanistan) }\end{array}$ & \multicolumn{2}{|c|}{$\begin{array}{l}\text { Reaction. The blue team then repeats the first } \\
\text { step to identify how the strategy can be } \\
\text { improved/confirm their strategy is appropriate. }\end{array}$} & PRT - R\&D \\
\hline Joint force support & \multirow{2}{*}{\multicolumn{2}{|c|}{$\begin{array}{l}\text { Record. A scribe records the conclusions to } \\
\text { ensure that follow up action is completed. }\end{array}$}} & $\begin{array}{l}\text { PRT - Counter } \\
\text { narcotics }\end{array}$ \\
\hline Afghan national army & & & PRT - Rule of law \\
\hline \multirow[t]{2}{*}{ Afghan national police } & & & Media liaison \\
\hline & Intelligence (Red) & Red team leader & \\
\hline
\end{tabular}

assets were assigned to the battle groups outside Central Helmand where Taliban activity was expected, not near the provincial capital. Hence, the Brigade commander and his staff had a clear picture of the situation 50 miles away from their headquarters but were blind just a few miles outside of it, a weakness ruthlessly exploited by the Taliban. The wargaming, however, enabled such assumptions to be surfaced and reviewed.

What these emerging patterns further did was creating areas of common understanding between the different stakeholder groups, the capabilities each could provide, and their issues. This was achieved by occasionally asking stakeholders to role-play other "blue" stakeholders, and to challenge their own arguments from others' perspectives, thereby counteracting groupthink and cognitive biases. Consequently, the wargaming process broke down personal, organizational, and cultural 
boundaries and got people engaging with other people and their hypotheses rather than with the deliberate and sequential analysis of data: it created a shared situational awareness.

Maintaining a shared situational awareness was the third and ongoing step of the process, as the situation on the ground would continuously evolve. For example, while the Royal Marines and other stakeholders went through the series of wargames to understand previous events and consider future implications, information was coming in through sources on the ground and in the air of impending Taliban attacks in other places within Central Helmand. Such intelligence would immediately be fed into the modified wargaming process to consider the validity of assumptions underpinning hypotheses and consequences for future intentions. This iterative refinement of understanding produced, within a two-week timeframe, an eighty percent explanation of what the Taliban had done, how, why, and what they intended to achieve by doing it, but also the resource, manpower, and morale implications of their temporary setback and potential future intentions.

The most important effect of the initial wargames was that it reduced the ambiguity of the situation to a level at which a range of possible futures could be foreseen (see Figure 4). Based on this, by late October 2008 each stakeholder could essentially determine what information they would need to further refine their understanding and create strategic options. However, the range of possible futures combined with the fast pace of events on the ground in which the Taliban still held

FIGURE 4. How the Steps of the Modified Wargaming Process Reduced the Ambiguity of Strategic Outcomes




the initiative meant that environmental uncertainty remained too high to develop a clear strategic direction. Time did not allow for this ambiguity to be reduced by identifying and tracking trigger events that would signal that the situation on the ground would move towards one or another possible future-a common practice in scenario planning. ${ }^{31}$ The reason for the lack of time was that the deadline for implementing the three original ISAF objectives for the 3 Commando Brigade's campaign had remained unchanged:

- governor-led eradication of poppies had to be achieved in January-March 2009;

- registration of 240,000 voters in January 2009 for the presidential election in August of that year; and

- development of the Afghan National Police in Central Helmand by the summer of 2009.

This meant that the implementation of the new strategy would have to start by late November/early December 2008 and lay the ground for the achievement of these three objectives. Further, the Royal Marines and their stakeholders did not have the resources to develop and pursue multiple strategies for a limited number of scenarios that collectively accounted for the probable range of future outcomes. The wargaming process provided, again, a way forward.

\section{Option Wargaming}

Finding the game-changer was the fourth step in the process. By comparing the shared situational awareness with the needs of the Afghan people, the stakeholders could see which pivotal objectives needed to be realized or explicitly avoided in order to create a cascade of favorable outcomes. This allowed the identification of potential game changing strategic concepts, and for the stakeholders to start moving from being adapters to shapers of the future. Further, wargaming of these potential concepts provided insights into the operational and organizational changes stakeholders would have to make in order to get into a position from which operations could be launched that would change the game and achieve the strategic objectives. For example, to prevent the Taliban from disrupting stabilization and reconstruction efforts, military and security forces would need to be brought in from outside Central Helmand. As the total number of forces available for the whole of Helmand province was fixed, this meant that battle groups would need to be reorganized. Similarly, scarce resources such as intelligence assets, bomb disposal experts, and logistics would need to be reallocated, and where possible new capabilities acquired. With the situation on the ground never being static, these operational and organizational changes towards shaping the future would not be without risk. The wargaming process, however, enabled the stakeholders to identify and review these risks, and to move to a position of understanding where an informed choice could be made about which of the tested strategic concepts to develop into a detailed plan.

\section{Concept Wargaming}

Planning for action was the fifth step in the process. At this point, conventional approaches to military strategy planning could be used such as the 
"Seven Questions" (see Figure 5). ${ }^{32}$ As the previous steps had created a shared situational understanding and common purpose (Questions 1-3 in the conventional approach), the planning teams within the various military and civil organizations used this planning approach from "Question 4" onwards. These questions facilitated the development of possible courses of action to realize the chosen

FIGURE 5. The "Seven Questions" Strategy Planning Approach in its Conventional Form and When Combined with Wargaming for Wicked Problems

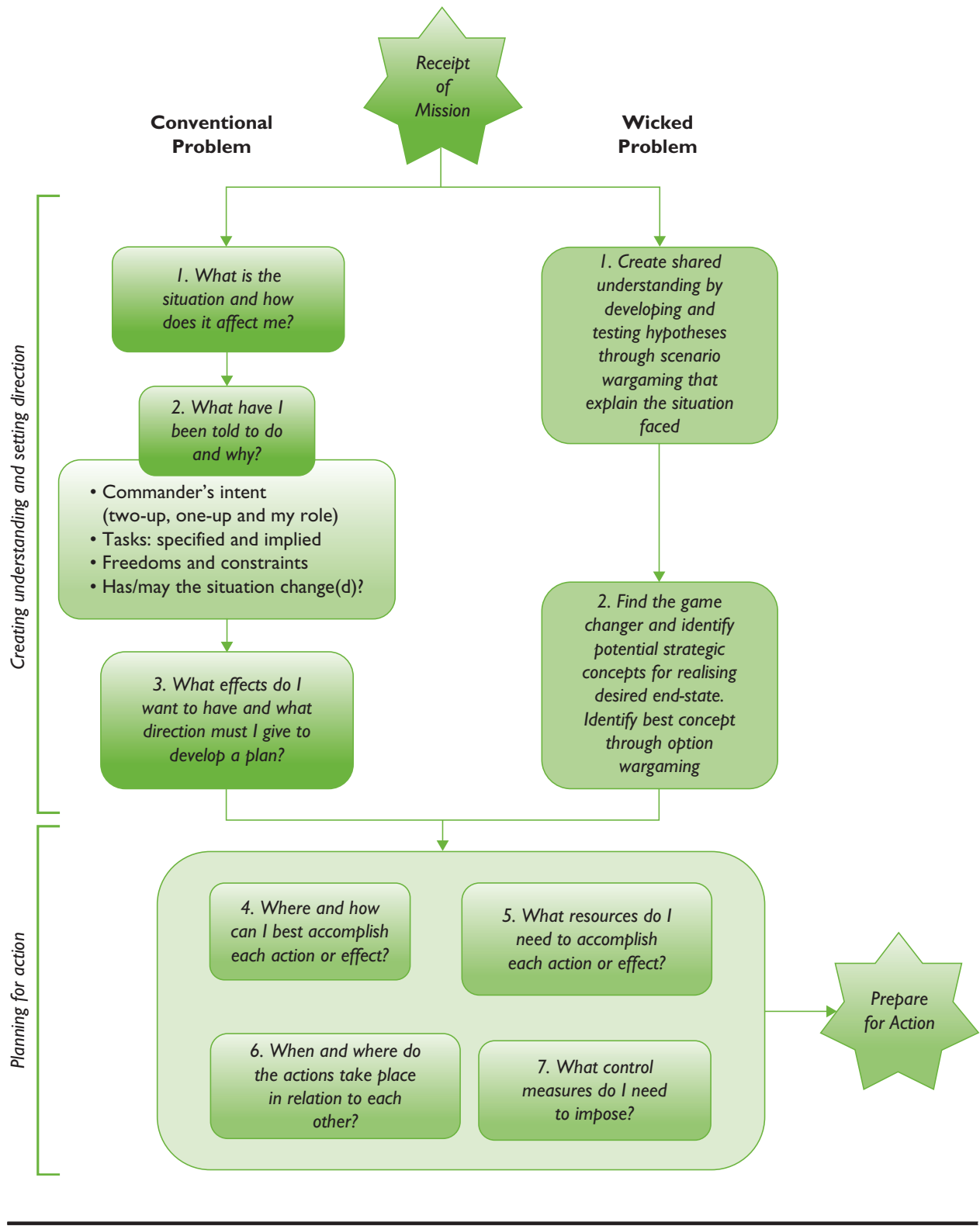


strategic concept, and estimated resource and scheduling requirements for each, taking into account the desired and unwanted outcomes as well as constraints discovered earlier in the wargaming process.

A factor that enabled the planning time needed to be compressed even further was that as a result of engaging all civil and military stakeholders, their subunits, and teams from the outset, planning by each organization could be conducted concurrently across all levels rather than in the typical consecutive top-down manner. For the planners in 3 Commando Brigade HQ, who were responsible for the coordination and integration of activities, this meant that the level of detail of their strategy plan was not limited to just one level down, i.e., the efforts assigned to the battle groups and supporting units constituting a brigade. The plan also included the efforts of each and every sub-unit and team constituting the Brigade's battle groups and supporting units. As a result, the Gantt chart for the new strategy plan consisted of 130 lines of enemy and friendly activities.

Throughout the development of possible courses of action ("Question 4"), mini-wargames would be conducted in their conventional guise with relevant stakeholder groups to test aspects of the overall plan and identify remedial actions. For example, the Military Stabilization Support Teams, which are small specialist teams that advise commanders of fighting units on reconstruction and development matters, would play a key role in ensuring potential District Governors would be willing to stand for election at the assembly to be held three days into the implementation of the new strategy in December 2008. To understand potential Taliban reactions based on their assessed intent and capabilities, and any counteractions needed, the relevant stakeholder groups involved would wargame their part of the plan, as illustrated in Figure 6.

FIGURE 6. Example of a Turn in a Course of Action Wargame

\begin{tabular}{|c|c|c|c|}
\hline Action & (Enemy) Reaction & Counter-Action & Record \\
\hline $\begin{array}{l}24 \text { hours into the } \\
\text { implementation of the } \\
\text { new strategy, MSSTs } \\
\text { locate all potential } \\
\text { District Governors and } \\
\text { confirm their } \\
\text { willingness to stand for } \\
\text { election at the } \\
\text { assembly to be held } \\
\text { two days later. }\end{array}$ & $\begin{array}{l}\text { Continue the } \\
\text { systematic intimidation } \\
\text { of local clan and family } \\
\text { elders to dissuade } \\
\text { them from cooperating } \\
\text { with ISAF and the } \\
\text { Provincial Governor. } \\
\text { To demonstrate } \\
\text { resolve, abduct and } \\
\text { assassinate a high } \\
\text { profile clan head. Send } \\
\text { out night letters during } \\
\text { the next cycle of } \\
\text { darkness advertising } \\
\text { the execution. }\end{array}$ & $\begin{array}{l}\text { Prior to the } \\
\text { implementation of the } \\
\text { new strategy, conduct } \\
\text { information operations } \\
\text { campaign to counter } \\
\text { Taliban efforts to } \\
\text { prevent new } \\
\text { governance structures } \\
\text { from emerging. Ensure } \\
\text { MSSTs are adequately } \\
\text { resourced to offer } \\
\text { inducements, e.g., } \\
\text { quick impact projects, } \\
\text { to overcome the fear } \\
\text { of retribution. }\end{array}$ & $\begin{array}{l}\text { The Information } \\
\text { Exploitation Group } \\
\text { takes away an action to } \\
\text { develop an information } \\
\text { campaign aimed at } \\
\text { countering Taliban } \\
\text { intimidation. The } \\
\text { Finance department } \\
\text { takes away an action to } \\
\text { provide additional } \\
\text { money to the MSSTs } \\
\text { to fund further quick } \\
\text { impact projects aimed } \\
\text { specifically at } \\
\text { supporting the } \\
\text { information campaign. }\end{array}$ \\
\hline
\end{tabular}




\section{Rehearsal of Concept}

Rehearsing the overall plan was the sixth step in the process of developing a new campaign strategy. This entailed 40-50 unit and sub-unit leaders, military and civil, physically walking through a large scale model of the area of operation, indicating what their actions would be at each key decision point along the timeline. This enabled participants as well as the Brigade planning team to visualize the effects of courses of actions and the Taliban's response in a sequential manner. Further, it enabled the Brigade commander, who stood back from the 2-hour rehearsal itself, to gain a big picture view of the plan in action and how it could evolve. Following the rehearsal of the plan, the planning teams would where necessary refine and then finalize the details of the plan.

\section{Strategy Execution}

Executing the strategy was the seventh and final step of the process, but also the beginning for the next iteration of the strategy-making process: in dynamic environments, strategy development and execution is a concurrent and continuous process, not a periodic event, as any actions taken fundamentally alter the situation to which others will react. Again, the wargaming process proved to be beneficial. As the strategy was developed, tested, refined, and rehearsed in an open and collegial way, a perceptible degree of self-synchronization developed during implementation. This meant that the diverse stakeholders were able to resolve issues rapidly among themselves without the requirement for extensive consultation with higher headquarters. Stakeholders knew what they were trying to do, they had a good understanding of what everyone else was trying to do, and therefore when problems arose, they were able to rapidly assess the situation and form solutions among themselves in line with the common intent. This made the whole organization, some 6,000 strong, extremely agile and adaptive-essential qualities in a dynamic and complex environment.

Although 3 Commando Brigade started their third tour of duty in Afghanistan's Helmand province with a strategy that lasted not more than three days, the new strategy developed interactively with more than a dozen different stakeholders in a 4-6 week period achieved the three ISAF objectives for the campaign and created a cascade of favorable outcomes that stood the test of time. ${ }^{33}$

\section{Discussion and Conclusion}

The purpose of this article is to understand what it takes to effectively make strategy as a network in the face of seemingly intractable problems. The elements necessary for such an approach were found through synthesis of literature from many different academic fields, leading to the argument for integrating these elements in a form of interactive and collaborative storytelling. The Royal Marines case study illustrated what such an approach can look like as well as its practical deployment. Given this grounding and expanding on the extant literature, it follows that this approach has broad applicability in all kinds of industries and markets-none of the elements are military-specific. 
What this case study highlights against the strategy literature in particular is the central role that storytelling naturally plays in individual and team sensemaking. The situation on the ground in Afghanistan, combined with the immovable deadline for achieving the three ISAF objectives, did not permit time for strategy classes, yet everyone involved was able to quickly understand and apply the principles of wargaming with minimal instruction. People are natural storytellers and the human brain is geared to learning through play. These aspects of human behavior are greatly under-appreciated in the strategy literature and practice. When we face a challenge, we don't start by asking, "What does Porter's Five Forces framework tell us to think about?" Instead, we ask, "What does the situation reminds us of? Is it something we faced in the past? Did that approach work, and would it here?" and explore options by asking, "What would happen if...?" The wargaming approach structures this narrative process in an orderly fashion so that many can participate simultaneously, premised by the fact that the principles of gaming empower the desire of stakeholders to participate and be rewarded. ${ }^{34}$

It is notable how relatively quickly the wargaming approach led to more than a dozen diverse organizations (i.e., different cultures, backgrounds, languages, and ways of working), involving many thousands of people, coming together and moving to a position from which they were successfully making strategy as one. Typically, these developments are measured in months or even years, not weeks, due to all kinds of organizational inertia (e.g., opposition from powerful vested interests, contractual issues, and limited resources). Although the Royal Marines started with a situation of disagreement among powerful stakeholder groups and significant resource constraints, there were no escalations of tensions or participants that metaphorically dug in deeper to defend their position; the opposite happened. The reason is that wargaming provided a safe context and simple structure for surfacing and debating contentious or critical issues. This triggers more easily insights and shifts in mindset than can be generated through reasoned arguments. Further, the process is about involving stakeholders early and collectively developing a vision for strategic change that engages participants on emotional, physical, intellectual, or even spiritual levels. When people are engaged early and given the freedom to discover and choose for themselves, and own the resulting story, they are far more likely to commit to the outcome than when told what to do. ${ }^{35}$

Although the role of narrative in addressing many of today's key leadership challenges is increasingly more recognized in the broader literature, the Royal Marines case study illustrates that the process of story crafting and telling for strategy making is different when viewed through the lens of a network. Contrary to popular notion, where a storyteller tells a story, authored perhaps by a select few, to an audience in the hope of sparking action (e.g., a CEO telling a "burning platform" story to his or her employees), in a network all participants are simultaneously author, actor, and audience. Further, in a network, this narrative process is not necessarily linear as groups at different levels can concurrently explore and create different narratives (wargames), the insights of which can be fed back or forward into others before one coherent, forward-looking narrative (strategy) emerges. That is, strategy as order emerges from chaos. ${ }^{36}$ However, given that wicked problems have no stopping rule, the narrative doesn't stop 
there: it continues to evolve during the execution of the strategy and throughout following cycles of strategy making.

As noted, the wargaming approach to strategy making can be applied in other contexts. For example, it can be used to expedite business integration following mergers and acquisitions, or to gain support for major public infrastructure initiatives such as airport expansions in densely populated areas. To illustrate the approach's broad utility, we briefly focus here on two real, recent instances of its application: the London Organizing Committee of the Olympic Games (LOCOG), and a world leader in healthcare products and services ("PharmaCo").

\section{LOCOG}

While LOCOG is not strictly dealing with strategic issues, it does routinely wrestle with seemingly intractable problems that require rapid resolution. This commercial organization, which was responsible for staging the 2012 Olympic and Paralympic Games in London, expanded quickly and by the time the Games had a workforce of almost 200,000 people $(6,000$ paid staff, 70,000 volunteers, and around 100,000 contractor roles). In addition, it had to deal with many international, national, and local partners, suppliers, sporting and government bodies, media, police, security, and transport. Of course, when the Games began, 14,700 athletes, 21,000 media and broadcasters, and millions of ticketholders were added to the mix. ${ }^{37}$ As a commercial organization, the bottom line matters but so do a number of other factors: for example, the immovable deadline of the Opening Ceremony, and the overriding imperative of delivering an unforgettable experience for competitors and spectators alike. These factors are frequently incompatible, yet there is no time to find an optimal solution with planning and execution occurring concurrently. The breadth, number, and power of stakeholders involved are breathtaking, and they must all be engaged to ensure that the Games are delivered. Rational, analytical, or directed problem solving does not work in this environment. Inspired by an earlier version of this article, LOCOG therefore decided to test the approach as detailed here. Following a successful trial period, wargaming has now become the process of choice within LOCOG for facilitating rapid adaptation to constantly changing circumstances.

\section{"PharmaCo"}

Until a few years ago, the world's leading pharmaceutical companies could rely on the sale of their blockbuster drugs to provide healthy revenues and profit growth. However, shrinking drug pipelines due to lack of in-house innovation, the expiry of patents on many blockbusters products, healthcare providers putting pressure on prices, and increasing threats from generic competition have forced leading drug companies to seek new strategies. Like many of its competitors, "PharmaCo" dealt with these challenges by shifting focus from selling drugs to health outcomes, and by restructuring sales, marketing, distribution, manufacturing, and clinical development in order to reduce costs. In some areas this meant doing more with less, but in many others it meant that core and non-core activities are increasingly being carried out by a large number of partners. However, concerns about the company's ability to maintain its competitive edge started to 
emerge when it was realized that outsourcing decisions in key areas had been made without full regard of their impact on other business areas. Second, competencies necessary for managing a large and diverse network were underestimated or lost as a result of job cuts. In an attempt to better understand the situation and identify ways for addressing the most pressing concerns, a multidisciplinary taskforce was set up. Appreciating that "problems cannot be solved by the same level of thinking that created them" (Einstein), this team decided to explore the utility of wargaming for their purposes. Although it is early days, the approach is enabling the development of better cross-functional relationships and common understanding. Initial wargames focusing on non-core activities have also indicated that a number of outsourcing contracts can be rationalized, securing further savings. Next, the taskforce will focus the wargaming on core business areas. Together with partner organizations, they intend to use these workshops to explore the business changes necessary for effectively collaborating on the development of pioneering healthcare solutions.

In a social world that changes constantly in complex, unpredictable, and uncontrollable ways, success increasingly depends on an organization's ability to form meaningful relationships with others and quickly learn how to adapt to new realities. Wargaming facilitates this in a simple and pragmatic way, making it a powerful strategy tool for networked organizations to effect change.

\section{Notes}

1. See, for example, R.E. Miles, C.C. Snow, J.A. Mathews, G. Miles, and H.J. Coleman, Jr., “Organizing in the Knowledge Age: Anticipating the Cellular Form," Academy of Management Executive, 11/4 (November 1997): 7-24; R. Gulati, N. Nohria, and A. Zaheer, "Strategic Networks," Strategic Management Journal, $21 / 3$ (March 2000): 203-215; R.E. Miles, C.C. Snow, and G. Miles, "TheFuture.org," Long Range Planning, $33 / 3$ (June 2000): 300-321; R.E. Miles, G. Miles, C.C. Snow, K. Blomqvist, and H. Rocha, "The I-Form Organization," California Management Review, 51/4 (Summer 2009): 61-76; Ø.D. Fjeldstad, C.C. Snow, R.E. Miles, and C. Lettl, "The Architecture of Collaboration," Strategic Management Journal, 33/6 (June 2012): 734-750.

2. See, for example, G. Hamel, Y.L. Doz, and C.K. Prahalad, "Collaborate With Your Competitorsand Win," Harvard Business Review, 67/1 (January/February 1989): 133-139; B.J. Pine II and J.H. Gilmore, "Welcome to the Experience Economy," Harvard Business Review, 76/4 (July/August 1998): 97-105; R. Gulati and D. Kletter, "Shrinking Core, Expanding Periphery: The Relational Architecture of High-Performing Organizations," California Management Review, 47/3 (Spring 2005): 77-104; L. Huston and N. Sakkab, “Connect and Develop: Inside Procter \& Gamble's New Model for Innovation," Harvard Business Review, 84/3 (March 2006): 58-66; R. Gulati, "Silo Busting: How to Execute on the Promise of Customer Focus," Harvard Business Review, 85/5 (May 2007): 98-108; R. Gulati, P. Puranam, and M. Tushman, "Meta-Organization Design: Rethinking Design in Interorganizational and Community Contexts," Strategic Management Journal, 33/6 (June 2012): 571-586.

3. See, for example, R. Stacey, "Strategy as Order Emerging from Chaos," Long Range Planning, 26/1 (February 1993): 10-17; R. Stacey, "The Science of Complexity: An Alternative Perspective for Strategic Change Processes," Strategic Management Journal, 16/6 (September 1995): 477-495; E.D. Beinhocker, "Strategy at the Edge of Chaos," The McKinsey Quarterly, 1 (1997): 109-118; R. Macintosh and D. Maclean, "Conditioned Emergence: A Dissipative Structures Approach to Transformation," Strategic Management Journal, 20/4 (April 1999): 297-316; J. Liedtka, "Strategic Planning as a Contributor to Strategic Change," European Management Journal, 18/2 (April 2000): 195-206; M. Pina e Cunha and J. Vieira da Cunha, "Towards a Complexity Theory of Strategy," Management Decision, 44/7 (2006): 839-850; J. Birkinshaw, J. Bessant, and R. Delbridge, "Finding, Forming, and Performing: Creating Networks for Discontinuous Innovation," California Management Review, 49/3 (Spring 2007): 67-84; H.W. Chesbrough and M.M. Appleyard, 
“Open Innovation and Strategy," California Management Review, 50/ (Fall 2007): 57-76; P.M. Senge, B.B. Lichtenstein, K. Kaeufer, H. Bradbury, and J.S. Carroll, "Collaborating for Systemic Change," MIT Sloan Management Review, 48/2 (Winter 2007): 44-53; E. Baraldi, "Strategy in Industrial Networks: Experiences from IKEA," California Management Review, 50/4 (Summer 2008): 99-126; C. Ernst and D. Chrobot-Mason, "Flat World, Hard Boundaries: How to Lead Across Them," MIT Sloan Management Review, 52/3 (Spring 2011): 81-88; J. Johanson and J.E. Vahlne, "Markets as Networks: Implications for Strategy Making," Journal of the Academy of Marketing Science, 39/4 (August 2011): 484-491.

4. H.W.J. Rittel and M.M. Webber, "Dilemmas in a General Theory of Planning," Policy Sciences, 4/2 (June 1973): 155-169; J.C. Camillus, "Strategy as a Wicked Problem," Harvard Business Review, 86/5 (May 2008): 98-106.

5. R. Axelrod, The Evolution of Co-operation (New York, NY: Basic Books, 1984).

6. See, for example, Stacey (1995), op. cit.; Beinhocker, op. cit.; E.D. Beinhocker, "Robust Adaptive Strategies," MIT Sloan Management Review, 40/3 (Spring 1999): 95-106; L.L. Bryan, “Just-In-Time Strategy for a Turbulent World," McKinsey Quarterly, 2 (2002): 17-27; D. Knights and F. Mueller, "Strategy as a 'Project': Overcoming Dualisms in the Strategy Debate," European Management Review, 1/l (Spring 2004): 55-61; C. Dibrell, J. Down, and L. Bull, “Dynamic Strategic Planning: Achieving Strategic Flexibility Through Formalization," Journal of Business and Management, 13/1 (2007): 21-35; S. Jermy, Strategy for Action (London: Knightstone Publishing Ltd., 2011).

7. See, for example, R. Charan and G. Colvin, "Why CEOs Fail," Fortune, June 21, 1999, pp. 68-78; G.L. Neilson, K.L. Martin, and E. Powers, "The Secrets to Successful Strategy Execution," Harvard Business Review, 86/6 (June 2008): 61-70; A. Franken, C. Edwards, and R. Lambert, "Executing Strategic Change: Understanding the Critical Elements that Lead to Success," California Management Review, $51 / 3$ (Spring 2009): 49-73; J. Hagel III, J. Seely Brown, D. Kulasooriya, and D. Elbert, The 2010 Shift Index: Measuring the Forces of Long-Term Change, Silicon Valley, USA, Deloitte Center for the Edge, 2010.

8. See, for example, J.M.T. Balmer and S.A. Greyser, "Managing the Multiple Identities of the Corporation," California Management Review, 44/3 (Spring 2002): 72-86; H. Bouchikhi and J.R. Kimberly, "Escaping the Identity Trap," MIT Sloan Management Review, 44/3 (Spring 2003): 20-26; Ernst and Chrobot-Mason, op. cit.

9. See, for example, D. Barry and M. Elmes, "Strategy Retold: Towards a Narrative View of Strategic Discourse," Academy of Management Review, 22/2 (1997): 429-452; G. Adamson, J. Pine, T. van Steenhoven, and J. Kroupa, "How Storytelling Can Drive Strategic Change," Strategy e Leadership, 34/1 (2006): 36-41; S. Denning, "Effective Storytelling: Strategic Business Narrative Techniques," Strategy $\theta$ Leadership, 34/1 (2006): 42-48; O. Brafman and R.A. Beckstrom, The Starfish and the Spider: The Unstoppable Power of Leaderless Organizations (London: Penguin Books, 2007); C. Aiken and S. Keller, "The Irrational Side of Change Management," McKinsey Quarterly, 2 (2009): 101-109; T. Amabile and S. Kramer, "How Leaders Kill Meaning at Work," McKinsey Quarterly, 1 (January 2012): 1-8.

10. See, for example, Brafman and Beckstrom, op. cit.

11. See, for example, E. Beinhocker, The Origin of Wealth: Evolution, Complexity, and the Radical Remaking of Economics (London: Random House Business Books, 2007); Jermy, op. cit.

12. See, for example, H. Simon, "Strategy and Organizational Evolution," Strategic Management Journal, 14 (Winter 1993): 131-142; J. Walsh, "Managerial and Organizational Cognition," Organization Studies, 6/3 (May/June 1995): 280-321; P. Lorange, "Strategy Implementation: The New Realities," Long Range Planning, 31/1 (February 1998): 18-29; G. Hamel, "The Why, What, and How of Management Innovation," Harvard Business Review, 84/2 (February 2006): 72-84; R.L. Martin, "Scientific Management is Past its Peak," BusinessWeek, May 22, 2007, p. 36; J.C. Camillus, “Strategy as a Wicked Problem," Harvard Business Review, 86/5 (May 2008): 98-106; I. Getz, "Liberating Leadership: How the Initiative-Freeing Radical Organizational Form Has Been Successfully Adopted," California Management Review, 51/4 (Summer 2009): 32-58; G. Hamel, "Moon Shots for Management," Harvard Business Review, 87/2 (February 2009): 91-98.

13. See, for example, M.S. Granovetter, "The Strength of Weak Ties," American Journal of Sociology, 78/6 (May 1973): 1360-1380; Stacey, op. cit.; M.J. Wheatley and M. Kellner-Rogers, "SelfOrganization: The Irresistible Future of Organizing," Strategy $\theta$ Leadership, 24/4 (July/August 1996): 18-24; A. de Geus, "The Living Company," Harvard Business Review, 75/2 (March/April 1997): 51-59; R. Cross and L. Prusak, "The People Who Make Organizations Go-Or Stop," Harvard Business Review, 80/6 (June 2002): 104-111; G. Kossinets and D.J. Watts, "Empirical Analysis of an Evolving Social Network," Science, 31 1/5757 (January 6, 2006): 88-90; Brafman and Beckstrom, op. cit. 
14. See, for example, A. Tversky and D. Kahneman, "Judgment Under Uncertainty: Heuristics and Biases," Science, 185/4157 (September 27, 1974): 1124-1131; J.F. Schmitt and G.A. Klein, "Fighting in the Fog: Dealing with Battlefield Uncertainty," Marine Corps Gazette, 80/8 (August 1996): 62-69; D. Lovallo and D. Kahneman, "Delusions of Success: How Optimism Undermines Executives' Decisions," Harvard Business Review, $81 / 7$ (July 2003): 56-63; Charles Roxburgh, "Hidden flaws in strategy," The McKinsey Quarterly, 2 (2003): 26-39; R. Stacey, "The Activity of Leading in Organizations: The Reflective and the Neurotic," Mt Eliza Business Review, 7/2 (Summer/Autumn 2005): 10-15; G. Steen, "Knowledge as Metaphor: Problems and Perspectives for KM," Proceedings of the European Conference on Intellectual Capital, 2010, pp. 545-552; D. Kahneman, D. Lovallo, and O. Sibony, "Before You Make That Big Decision," Harvard Business Review, 89/6 (June 2011): 50-60.

15. See, for example, Dibrell, Down, and Bull, op. cit.; H. Mintzberg, B. Ahlstrand, and J. Lampel, Strategy Safari: The Complete Guide Through the Wilds of Strategic Management (Harlow, UK: Pearson Education, 2009); Jermy, op. cit.

16. Rittel and Webber, op. cit.

17. H.R. Yarger, Strategic Theory for the $21^{\text {st }}$ Century: The Little Book on Big Strategy, US Army War College, 2006; A. Franken, C. Paton, and S. Rogers, "How the UK's Royal Marines Plan in the Face of Uncertainty," Harvard Business Review, web exclusive (November 2010): 1-6; T.X. Hammes, "Assumptions: A Fatal Oversight," Infinity Journal, 1 (Winter 2010): 4-6; T.X. Hammes, "Limited Means Strategy: What To Do When the Cupboard is Bare," Infinity Journal, 3 (Summer 2011): 8-10; M.L.R. Smith and J. Stone, "Explaining Strategic Theory," Infinity Journal, 4 (Fall 2011): 27-30; Jermy, op. cit.

18. See, for example, Rittel and Webber, op. cit.; Axelrod, op. cit.; R.M. Ryan and E.L. Deci, "SelfDetermination Theory and the Facilitation of Intrinsic Motivation, Social Development, and Well-Being," American Psychologist, 55/1 (January 2000): 68-78; Birkinshaw, Bessant, and Delbridge, op. cit.; Camillus, op. cit.; L.L. Berry, A.M. Mirabito, and W.B. Baun, "What's the Hard Return on Employee Wellness Programs?" Harvard Business Review, 88/2 (December 2010): 104-112; D.H. Pink, Drive: The Surprising Truth About What Motivates Us (Edinburgh: Canongate Books Ltd, 2010); Ernst and Chrobot-Mason, op. cit.

19. See, for example, N. Dixon, Perspective on Dialogue: Making Talk Developmental for Individuals and Organizations (Greensboro, USA: Center for Creative Leadership, 1996); J.M. Liedtka and J.W. Rosenblum, "Shaping Conversations: Making Strategy, Managing Change," California Management Review, 39/1 (Fall 1996): 141-157; Liedtka, op. cit.; P.M. Senge, The Fifth Discipline: The Art and Practice of the Learning Organization, $2^{\text {nd }}$ ed. (London: Random House, 2006); R. Gilkey and C. Kilts, "Cognitive Fitness," Harvard Business Review, 85/11 (November 2007): 53-66; S. Kaplan, "Framing Contests: Strategy Making Under Uncertainty," Organization Science, 19/5 (September/October 2008): 729-752; G. Klein, S. Wiggins, and C.O. Dominguez, "Team Sensemaking," Theoretical Issues in Ergonomics Science, 11/4 (2010): 304-320.

20. See, for example, H. Courtney, J. Kirkland, and P. Viguerie, "Strategy Under Uncertainty," Harvard Business Review, 75/6 (November/December 1997): 67-79; E. Bonabeau, "Predicting the Unpredictable," Harvard Business Review, 80/3 (March 2002): 109-116; K.D. Miller and H.G. Waller, "Scenarios, Real Options and Integrated Risk Management," Long Range Planning, 36/1 (February 2003): 93-107; G.S. Day and P.J.H. Schoemaker, "Scanning the Periphery," Harvard Business Review, 83/11 (November 2005): 135-148; P.J.H. Schoemaker and G.S. Day, "How to Make Sense of Weak Signals," MIT Sloan Management Review, 50/3 (Spring 2009): 81-89; S. Makridakis, R.M. Hogarth, and A. Gaba, "Why Forecasts Fail. What to Do Instead?" MIT Sloan Management Review, 51/2 (Winter 2010): 83-90.

21. See, for example, F. Westley, "Middle Managers and Strategy: Micro Dynamics of Inclusion," Strategy Management Journal, 11 (1990): 337-351; S. Oswald, K. Mossholder, and S. Harris, "Vision Salience and Strategic Involvement: Implications for Psychological Attachment to Organization and Job," Strategic Management Journal, 15/6 (July 1994): 477-489; K.E. Weick, Sensemaking in Organizations (Thousand Oaks, CA: SAGE Publications, 1995); Dixon, op. cit.; Liedtka and Rosenblum, op. cit.; Barry and Elmes, op. cit.; C.M. Christensen and M. Overdorf, "Meeting the Challenges of Disruptive Change," Harvard Business Review, 78/2 (March/April 2000); Ryan and Deci, op. cit.; S. Carapiet and H. Harris, "Role of Self-Organisation in Facilitating Adaptive Organisation: A Proposed Index for the Ability to Self-Organise," Production Planning $\theta$ Control, 18/6 (September 2007): 466-474; Kaplan, op. cit.; S. Mahmud, "Framework for the Role of Self-Organization in the Handling of Adaptive Challenges," Emergence: Complexity o Organization, 11/2 (2009): 1-14; J. Medina, Brain Rules: 12 Principles for Surviving and Thriving at Work, Home and School (Seattle, WA: Pear Press, 2009); Klein, Wiggins, and Dominguez, op. cit.; C. Fenton and A. Langley, "Strategy as Practice and the Narrative Turn," Organization Studies, 32/9 (September 2011): 1171-1196. 
22. See, for example, Liedtka, op. cit.; J. Surowiecki, The Wisdom of Crowds: Why the Many are Smarter than the Few and How Collective Wisdom Shapes Business, Economies, Societies and Nations (New York, NY: Doubleday, 2004); R.L. Martin, "How Successful Leaders Think," Harvard Business Review, 85/6 (June 2007): 60-67; T. Brown, Change by Design: How Design Thinking Transforms Organizations and Inspires Innovation (New York, NY: HarperCollins Publishers, 2009); A. Borison and G. Hamm, "Prediction Markets: A New Tool for Strategic Decision Making," California Management Review, 52/4 (Summer 2010): 125-141.

23. Beinhocker, op. cit.; Miller and Waller, op. cit.; Franken, Paton, and Rogers, op. cit.; Hammes, op. cit.; Smith and Stone, op. cit.; Jermy, op. cit.

24. On "purpose more important than task" see, for example, G. Klein and T.E. Miller, "Distributed Planning Teams," International Journal of Cognitive Ergonomics, $3 / 3$ (1999): 203-222; Franken, Paton, and Rogers, op. cit. On "strategic flexibility and agility" see, for example, R. Sanchez, "Strategic Flexibility in Product Competition," Strategic Management Journal, 16 (Summer 1995): 135-159; J. Baker, "Agility and Flexibility: What's the Difference?" Cranfield School of Management Working Paper, 1996, <dspace.lib.cranfield.ac.uk/bitstream/1826/1151/1/ SWP05-96.pdf>; E. Santos Bernardes and M.D. Hanna, "A Theoretical Review of Flexibility, Agility and Responsiveness in the Operations Management Literature," International Journal of Operations and Production Management, 29/1-2 (2009): 30-53.

25. See, for example, Wheatley and Kellner-Rogers, op. cit.; De Geus, op. cit.; Lichtenstein, op. cit.; Y. Doz and M. Kosonen, "The Dynamics of Strategic Agility: Nokia's Rollercoaster Experience," California Management Review, 50/3 (Spring 2008): 95-118; Mahmud, op. cit.; Y. Doz and M. Kosonen, "Embedding Strategic Agility: A Leadership Agenda for Accelerating Business Model Renewal," Long Range Planning, 43/2-3 (April 2010): 370-382; H. Bahrami and S. Evans, "Super-Flexibility for Real Time Adaptation: Perspectives from Silicon Valley," California Management Review, 53/3 (Spring 2011): 21-39.

26. See, for example, Ryan and Deci, op. cit.; Brafman and Beckstrom, op. cit.; S. Sinek, Start With Why: How Great Leaders Inspire Everyone To Take Action (London: Portfolio Penguin, 2009).

27. See, for example, L. Heracleous and C. Jacobs, "The Serious Business of Play," MIT Sloan Management Review, 47/1 (Fall 2005): 19-20; A.D. Pellegrini, D. Dupuis, and P.K. Smith, "Play in Evolution and Development," Development Review, 27 (2007): 261-276; M. Wenner, "The Serious Need for Play," Scientific American Mind, 20 (February/March 2009): 22-29; S. Brown, Play: How It Shapes the Brain, Opens the Imagination, and Invigorates the Soul (New York, NY: Penguin Group, 2009).

28. De Geus, op. cit.; Pellegrini, Dupuis, and Smith, op. cit.; Wenner, op. cit.; Brown, op. cit.

29. Pellegrini, Dupuis, and Smith, op. cit.; Brown, op. cit.

30. See, for example, P.P. Perla, The Art of Wargaming (Annapolis, MD: Naval Institute Press, 1990); M. Caffrey, "Toward a History Based Doctrine for Wargaming," Air e Space Power Journal, <www.airpower.maxwell.af.mil/airchronicles/cc/caffrey.html>; De Geus, op. cit.

31. See, for example, K. van der Heijden, R. Bradfield, G. Burt, G. Cairns, and G. Wright, The Sixth Sense: Accelerating Organizational Learning with Scenarios (Chichester, UK: John Wiley \& Sons Ltd., 2002); P. Cornelius, A. van der Putte, and M. Romani, "Three Decades of Scenario Planning in Shell," California Management Review, 48/1 (Fall 2005): 92-109.

32. Franken, Paton, and Rogers, op. cit.

33. For more details about 3 Commando Brigade's deployment to Afghanistan's Helmand Province in 2008, see E. Southby-Tailyour, 3 Commando Brigade: Helmand Assault (London: Ebury Press, 2010).

34. J.J. Huizenga, Homo Ludens: A Study of the Play Element in Culture (London: Beacon Press, 1992); Weick, op. cit.; Barry and Elmes, op. cit.; Denning, op. cit.; Medina, op. cit.; Klein, Wiggins, and Dominguez, op. cit.; Sinek, op. cit.; F. Rose, The Art of Immersion: How the Digital Generation is Remaking Hollywood, Madison Avenue and the Way We Tell Stories: Entertainment in a Connected World (New York, NY: W.W. Norton \& Company, 2010); Amabile and Kramer, op. cit.

35. Oswald, Mossholder, and Harris, op. cit.; Weick, op. cit.; Brafman and Beckstrom, op. cit.; Aiken and Keller, op. cit.; Sinek, op. cit.

36. Stacey, op. cit.

37. www.london2012.com/about-us/the-people-delivering-the-games/the-london-organisingcommittee/.

California Management Review, Vol. 55, No. 3, pp. 107-133. ISSN 0008-1256, eISSN 2162-8564. () 2013 by The Regents of the University of California. All rights reserved. Request permission to photocopy or reproduce article content at the University of California Press's Rights and Permissions website at http://www.ucpressjournals.com/reprintinfo.asp. DOI: 10.1525/cmr.2013.55.3.107. 
Copyright of California Management Review is the property of California Management Review and its content may not be copied or emailed to multiple sites or posted to a listserv without the copyright holder's express written permission. However, users may print, download, or email articles for individual use. 